\title{
PROMOTING LEARNER AUTONOMY IN AN ESL CONTEXT IN PAKISTANI UNIVERSITIES: A TEACHERS' PERSPECTIVE
} Asma Kashif Shahzad ${ }^{1 *}$, Akifa Imtiaz ${ }^{2}$, Tahira Asgher ${ }^{3}$

${ }^{1 *}$ Assistant Professor, Department of Humanities, COMSATS University Islamabad, Vehari Campus, Pakistan;

${ }^{2}$ Assistant Professor, Department of English, Fatima Jinnah Women University, Rawalpindi, Pakistan; ${ }^{3}$ Assistant Professor, Department of English Linguistics, The Islamia University of Bahawalpur, Pakistan.

Email: ${ }^{1 *}$ asmashahzad@ cuivehari.edu.pk, ${ }^{2}$ akifa.imtiaz@fjwu.edu.pk, ${ }^{3}$ tahira.asgher@iub.edu.pk

\section{Article History: Received on $12^{\text {th }}$ June 2021, Revised on $18^{\text {th }}$ June 2021, Published on $21^{\text {st }}$ June 2021}

\begin{abstract}
Purpose of the study: The present research aims to study the effectiveness of using learner autonomy in English language classrooms at the university level from teachers' perspectives. The study seeks to determine what roles can be performed by the language teachers while fostering learner autonomy at the university level.

Methodology: The study is descriptive and qualitative. The data has been collected with the help of a structured interview. The researchers prepared a list of questions to collect data from the interviews with 19 ESL teachers. The respondents are from the five universities of South Punjab. The interviews are recorded and transcribed and further analysed in terms of thematic categories discussed with the teachers.
\end{abstract}

Main findings: The research explores a great deal of awareness of the concept of learner autonomy among university teachers, which they use indirectly or directly in their classroom teaching. The teachers discuss many roles they can perform to develop and use autonomy in the English language classroom. They express that practising autonomous learning in an ESL context could result in learning the English language more naturally and effectively.

Application of this study: The present study contributes to using and developing learner autonomy in an ESL context. It would be an inspiration to research and explore more avenues of systematic inquiry in the field it deals with. The pedagogical implication of the study is that it would help ESL teachers practice the concept in their classroom teaching effectively.

Novelty/Originality of this study: Most of the studies found in the field of learner autonomy are learner-centered. our research explores the phenomenon from the viewpoint of language teachers. The study focuses on the effectiveness of learner autonomy perceived by the teachers. It further records the teachers' opinions about what role(s) they can perform to practice it in the classroom.

Keywords: ESL/EFL Classroom, Autonomous Learning, Pakistan, University Teachers, ELT.

\section{INTRODUCTION}

The term 'autonomy' has originated from moral philosophy and politics. It is a term that is confused extensively with the terms self-learning or learning independently. It is a 'multifaceted notion' that has been explored and researched by many academic figures to understand the concept, and many proportions of the study have been deliberated so far concerning learning and teaching (Fedj \& Benaissi, 2018). Learner autonomy is the ability to control one's learning. Since 1970, many works have been done on how teachers can contribute to its progress. Teachers need to know a student's motivation, knowledge, and attitude. The educator's role is to prepare learners as responsible members of society and enables them "to take control over their learning" (Holec, 1981, p.3).

The process of learner autonomy has three stages. The first one is raising student awareness. The second stage is changing attitudes, and the third stage is transforming rules. Autonomy is all about the abilities and attitudes of an individual that is affected by the social and cultural constraints of the learner (Yasmeen et al., 2017). Mobile technology and the broader scope of social media have advanced learner autonomy and language learning and language learners all over the world have realized the significance of using technology that further motivates them to work independently

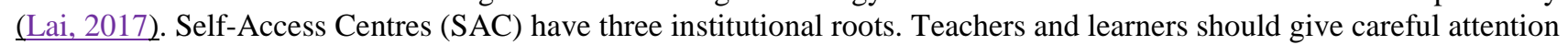
to the success of self-access centres. According to Zhong (2018), teachers should help the students find their voice and promote learner autonomy. The ministry of education in China granted college English curriculum fundamentalism in 2007. The purpose was to inspire colleges across the country to develop and use the teaching model to create autonomous learners.

The learners must have to be trained and authorized to monitor his/her learning at any stage of the learning if needed or required but an active role of the teacher in monitoring and establishing autonomy in classroom learning is indispensable. Without it, the practice of autonomy becomes challenging and ultimately impossible (Yildiz, \& Celik, 2017; Yildiz, 2017). The teachers' role must support the classroom settings and environment for practising autonomy by the learners. So, the concept of controlling or taking charge of one's own learning is considered a central and essential principle by many researchers (Schneider, 2018). 
Autonomous learners have a clear perception of their learning styles and techniques. Dickinson (1994) says that preparation for autonomy should be given to learners. The learners and the teachers also need to be prepared for selfaccess. In a classroom, the teacher must act as "a resource" and be patient and get help from colleagues. When the teachers are involved in self-access, they must act as a "counsel" and learn by raising consciousness. The present study investigates how far autonomous learning is considered feasible and desirable for secondary-level ESL teachers and how they think it helps promote English Language teaching.

\section{Autonomy and English Language Learning in Pakistan}

Learner autonomy, in structured instructional settings, includes reflective participation in the preparation, implementation, supervision, and evaluation of learning. However, it is essential to remember that language acquisition is entirely dependent on language use: we cannot learn to communicate without listening, nor can we learn to read without reading. Informal language learning, the extent of learner autonomy is often limited by the learner's ability to do so in the target language; in other words, the scope of our autonomy as language learners is partially determined by our autonomy as target language users.

In Pakistan, the concept of autonomous learning is not very familiar to the teachers, and its implication has not appeared in language learning discourse. Some of the constituents of this notion may be found practicable with some synonymous terms in language teaching and learning, and that the concept should be presented to the language teachers in its full spirit and structure (Yasmeen \& Sohail, 2018c). In another study, Yasmeen \& Sohail (2018b) collected the teachers' reflections with particular reference to English language teachers' beliefs about learner autonomy.

Considering the results and conclusions by Yasmeen and Sohail (2018a, 2018b), this study endeavoured to explore the views of the English language teachers how far they consider learners autonomy effective in an ESL context and what role could be performed by the teacher to develop autonomy in an ESL classroom.

\section{Research Questions}

The study aims to investigate the following research questions:

1. What are ESL teachers' views about the effectiveness of learner autonomy in an ESL classroom at the university level?

2. What role may be played by the ESL teacher in developing learner autonomy?

\section{LITERATURE REVIEW}

The ancestries of the exploring autonomy in language teaching and learning can be dated back to the mid-1970s. (Holec, 1981; Broady \& Kenning, 1996; Littlewood, 1999; Smith, 2008). The history of probing a deeper insight of using autonomy in EFL/ESL includes the studies conducted mostly with learners with a broader spectrum of associating the concept with technology (Honarzad \& Rassaei, 2019; Liu et al., 2020; Godwin-Jones, 2019). Until now, it is still of the unparalleled interest of inquiries in the fields of self-regulation, motivation and anxiety, sociocultural theory, and language teacher development (Wu, 2018). Aslam \& Yasmeen (2018) investigated the role of motivation and attitudes and beliefs of learners towards learner autonomy. They concluded that at the university level, the learners could better learn the English language independently and their attitude towards autonomous learning is positive to a great extent.

Efforts to bridge the gap between theory and practice have resulted in developing language teaching and learning approaches, processes, and techniques. On the assumption that it was more accountable than the current one, a process or strategy was quickly replaced by another for a long time. These methods are based on some assumptions regarding learning and learning processes. These theories were based on studies and advances in psychology and linguistics. The incremental change in emphasis of these studies from different curriculum components to the learner, in particular, appears to be witnessing the revision of the question "How do humans learn a language?" to "How does a person learn a language?" In Dickinson's (1994) concept of an autonomous learner, the term "responsible" refers to a person's capacity to make and execute all of his own learning decisions.

Consequently, accountability is the learner's inspiring quality that shows itself in the learner's small choices to tailor teaching to his needs. Little (1991) defines autonomy as the ability to separate, reflect critically, make decisions, and behave independently. He defines accountability as "power over the cognitive processes that underpin successful learning self-management". Metacognitive techniques, such as thinking about the learning process, planning for learning, tracking the learning mission, and self-evaluation, are closely linked to autonomy. Holec (1981) describes autonomy in the sense of foreign language learning as the ability to control one's own learning. As a result, an autonomous learner is someone capable of managing his or her own learning. For independent learners, the teacher's job is to assist them in taking responsibility for their own learning decisions by 1) deciding the objectives; 2) identifying the contents and progressions; 3 ) choosing methods and techniques to be used; 4) properly tracking the acquisition procedure (rhythm, time, location, etc.); and 5) assessing what has been acquired. 


\section{Empirical Research of the Role of Teacher in Learner Autonomy}

Many studies have explored the role that a language teacher may perform to develop learners autonomy in the language classroom (Knowles, 1975; Nunan, 1993; Holec, 1995; Voller, 1997; Yang, 1998; Aoki, 2000; Xu \& Xu, 2004; Xu, 2007; Borg \& Al-Busaidi, (2012); Han, 2014; Falah Alzubi et al., 2017; Yasmeen \& Sohail, 2018b; Booma \& Swatevacharkul, 2020; Yildiz\&Yucedal, (2020). The studies that focus on students are found relatively more in vogue, and the research that empirically investigates the role of the teachers in the domain is relatively limited.

$\mathrm{Xu}$ and $\mathrm{Xu}$ (2004) conducted research and collected data from the students regarding their perceptions of what roles can be performed by the teacher regarding developing learner autonomy. The teachers may perform the role of facilitators, guides, organisers, inspirators, monitors, evaluators, role suppliers, and atmosphere creators ( $\mathrm{Xu} \& \mathrm{Xu}, 2004)$. Han (2014) commented that although the study mentioned above listed the roles of the teachers to foster learner autonomy in a language classroom, it was only the perspective of students. Yasmeen and Sohail (2018b, 2018c) examined English language teachers' beliefs regarding learner autonomy and found out that teachers have been practising autonomous learning strategies without knowing that.

Shi \& Han (2019) investigated the role of cooperative group learning in improving learner autonomy. They found that collaborative and group work support the students' motivation and attitudes toward learning a language. The study concluded that students performed more actively and their ability to reach sources enhanced a great deal in collaborative learning.

This study contributes to the knowledge of the existing field as it investigates the views and perceptions of the English language teachers about the effectiveness of exercising learner autonomy at the university level and what role they can play to develop learner autonomy in an ESL Classroom Pakistani context.

\section{METHODOLOGY}

The researchers adopted a descriptive approach to carry out the study. The qualitative research method was employed to transcribe, analyse, and interpret the collected data.

\section{Data Collection Tools and Method}

The data was collected through a structured interview. A list of questions was prepared to collect data from the university teachers. The list has consisted of two parts. The first part explains the English language teachers' perceptions about the effectiveness of learner autonomy, and the tool was adapted from Yasmeen \& Sohail (2018b). The researchers modified the questions according to the context of the study. The second part interrogates the roles of the teachers in the light of the categories identified by $\mathrm{Xu} \& \mathrm{Xu}$ (2004). The interviews were conducted and recorded through online meeting tools i.e. Zoom and Google Meet.

\section{Respondents}

The respondents were the English language teachers that were taken from the population of the five universities of South Punjab, including Bahauddin Zakariya University, Multan, The Islamia University, Bahawalpur, Ghazi University, DG Khan, Education University, Multan Campus, COMSATS University Islamabad, Vehari campus. A total of 19 teachers have been selected to collect the data regarding their perceptions about learner autonomy. The teachers selected for the study have more than five years of teaching experience.

\section{Data Analysis}

The data collected through the online recorded meetings were transcribed and theses were categorized. A content analysis was conducted by categorising the items of the list of questions prepared for the interview under various themes about which the questions are asked and henceforth interpreted from the recorded interviews.

\section{Themes for Items asked in Structured Interview}

The themes that were used as the basis of the items in the list of questions were as follows:

1. Understanding of the construct of learner autonomy

2. Explanation of the concept of independent learning

3. Effectiveness of learner autonomy in an ESL context

4. The role of teacher to develop learner autonomy

5. Feasibility of practising learner autonomy

\section{DISCUSSION}

As discussed earlier, the interviews were recorded and transcribed to answer the research questions. The results obtained from the opinions and answers of the respondents were assorted. The thematic analysis of the data collected concerning each category is presented in this section. 


\section{Understanding of the construct of learner autonomy}

Almost all of the teachers said they are familiar with the term and had quite a good understanding of the term. Some of them reported that they had conducted some undergraduate research projects to study the feasibility of using learner autonomy in language classroom at the secondary level. This finding is entirely contrary to the one described in Yasmeen \& Sohail (2018b), where they reported that their respondents were not familiar with the term 'autonomy'. A teacher added that he had supervised an M.Phil. thesis on the topic in which the respondents were the students of public schools. He added:

The concept of autonomy in the language classroom is not alien to us, the teachers. In fact, we are practising it in the class knowingly or unknowingly, consciously or unconsciously. Students in universities, especially in large classes, can be taught better if they are given a part of their course materials for independent studies.

Above all, autonomous learning does not mean learning something in isolation.

It is pretty clear that the concept is not vague to the university teachers, and they have almost an absolute understanding of what learner autonomy stands for.

\section{Explanation of the concept of independent learning}

The question of explaining the concept of independent learning in the ESL context was answered quite rigorously and explicitly by the teachers. Despite diversified and multidimensional research in the field of learner autonomy, the concept is still somewhat hard to explain (Borg \& Al-Busaidi, 2012). The teachers described several different explanations of the idea that are given as under:

\section{Independent learning as an innate phenomenon}

The teachers described autonomy as a natural and in-built phenomenon. Almost half $(\mathrm{N}=10)$ argued that it is just like how a child learns her/his first language without monitoring or knowing the linguistic categories of her/his first language. They argued that language acquisition is an automatic process, and it is taught best when the learner is autonomous. Some teachers claimed that students had acquired the fundamental knowledge of the English language at the university level. So, at this level, they are motivated to learn themselves. Almost all of them stressed that the learners could learn more effectively if they are intrinsically motivated and adequately instructed and guided by the teachers. one of the teachers explained:

Learning is an inborn capacity of all human beings. The same case is with language that is learnt by all the individuals who are capable of doing so. A student can learn a language on his/her own if he is motivated to learn it, especially at the university. In my view, learning a second language is somehow similar to learning our native language.

The study conducted by Yasmeen \& Sohail (2018b) concluded that almost all of their participants declined autonomy as an innate ability. However, in the present study, nine participants consider it debatable and stressed that autonomous learning in the language is only the characteristic of first language acquisition when a child learns her/his first language from their environment. According to them, the notion does not apply to a second language learning context. One of the teachers said:

For most of our students, English is just like a foreign language. they seldom use it outside of the classrooms. It is not justified to compare the learning of English with learning a native language or the mother tongue.

They called it relatively impractical in teaching and learning the English language as Sinclair (2000) asserted that the autonomy in language learning could not be regarded as innate.

\section{Autonomy is learners' attribute}

The teachers, who claimed that autonomy is a natural process, denoted it as an ability specific to the learners. The teachers said that when a learner is given autonomy, she/he becomes responsible for her/his own learning. The majority of the teachers stated that the university students could set the objective and goal and decide on the method and strategies to work independently in and outside the classroom settings. According to most teachers $(\mathrm{N}=14)$, students at the university level must not be dealt with like beginners and should be given autonomy to explore something more than traditional teaching. One teacher added that:

when we give students the freedom to work on their assignments, they learn and explore some extra information relevant to that topic. This is the best way to increase their knowledge and, I believe, such a set of information is more effectively learnt by the learners.

\section{Effectiveness of learner autonomy in an ESL context}

Most of the teachers confirmed that autonomy in language learning results in the effective learning of a second language: 
English in our context. A collective point of opinion was recorded on the construct that autonomous learning has a relationship with the enhanced motivation of the learners in learning a second language. The teachers expressed that the students feel happier and more independent when they are given autonomy and learn better than less autonomous students in the English language classroom at the university level. They shared many experiences where they asserted that independence or giving students charge of their learning made them more confident, proficient, and pleased. One of the teachers explained:

If the student is reproducing what has already been taught in the classroom, he/she is not learning in its full spirit. He must be given some additional material/sources to explore the field of knowledge and improve his/her knowledge. While exploring and browsing for the relevant information, he/she will be able to get some extra knowledge that would help him/her develop confidence about learning English.

A strong agreement was recorded on the concept that autonomous learners are more enthusiastic and excited about their learning. A respondent added:

Students feel more energy when they are given the powers to learn themselves. Autonomy helps them get out of that traditional classroom concept where they are supposed to sit and listen to what teachers instruct.

While discussing the age factor, most of the teachers disagreed that autonomy can help at the beginning level. They firmly advocated that only the adult learner benefits from autonomous learning. The expression of one of them was recorded as:

As they (learners) grow up, they become more responsible for what they should do with their learning. Learner autonomy may be said to be the most effective with adult English learners as a second language. moreover, they can not only learn what is assigned rather they improve their communicative skills if they are working with their classmates.

One of the teachers concluded that for most of the learners, autonomy is a new experience and something that they have never done before. However, some teachers supplemented that as a unique experience, autonomy can only be practical if the teachers can identify the boundaries and learners have been introduced to some rules of exercising it. All teachers concluded that autonomy is the best tool to improve language learning while working and learning in collaboration. This collaboration helps them learn to communicate more politely and make them patient listeners.

\section{The role of teacher to develop learner autonomy}

As discussed in the literature review, most of the studies regarding the teachers' role in using autonomy in the classroom or the English language classroom are learners-centered. In our study, teachers unanimously approved that English language teachers can effectively develop autonomy in English language classrooms. They argued that a teacher can perform best as a facilitator in such situations and that he/she can help learners to create an environment of collaboration and teamwork while working independently. Some teachers explained that monitoring the class and guiding them towards the right direction of learning to keep them active and interactive in the classroom. They further added that continuous counselling and control of the activities in the classroom practices would assist learners and teachers both to identify the marked difference between learning something with or without the teacher's help. The teachers explained this and said that autonomy could never be taken as learning something without teacher presence. They stressed that the teacher's presence is indispensable even learners are working independently for effective teaching and learning. The expression of one of the teachers is given as under:

Yes, the presence of a teacher can never be denied. The teacher may perform the role of a facilitator, guide, helper, monitor, supporter, organiser, or whatever his/her control must be there to create the environment conducive to effective learning. Learner autonomy could never be taken as working or learning alone.

Another role of the teachers to foster autonomy is that of supplier of the materials and instructor. The teachers argued that even if the learners are given space to learn independently, teachers should provide materials or resources. They further elaborated:

A language teacher should be responsible for providing all the learning materials and resources to the learners to keep the learning process on track.

The roles that have been identified in the present study are very similar to Xu \& Xu (2004), who extracted the roles of the teacher from the opinions collected from the students' responses concerning learner autonomy.

\section{Feasibility of practising learner autonomy}

The last section was about how feasible it is to practice learner autonomy in an ESL context. All of the respondents agreed that it is quite feasible to practice it with adult learners at the university level. But, $N=12$ stated that some students may not be able to work independently and they might not feel confident in a situation where they are given a free hand. They argued that teachers' role is very significant in the case where students need help and assistance. One of the teachers suggested that: 
It is crucial to engage less motivated or an average student to work independently. As regards the feasibility of working independently in a language classroom, a teacher should be there to help him/her. A teacher is responsible for motivating, guiding, assisting, and evaluating the students who are unable to learn autonomously.

The teachers further argued that the less motivated or average students may not also work better and effectively with the help of their motivated class fellows. They need a teacher to facilitate and guide them.

The teachers explained that the prevailing educational system in universities hardly supports teachers to practice learner autonomy in the class as it is teachers-centered and examination-based. They suggested that the concept should be formally introduced to practice effectively in the educational system. The teachers further added that proper training should be offered to the university teachers for developing and practising autonomy in English language classrooms.

\section{CONCLUSION}

The present research aimed to explore the perceptions of university teachers in Pakistan about learner autonomy in an ESL context. The discussions explained that the teachers at the university level were quite aware of autonomy and have already been practising it to some extent in teaching the English language. It is concluded that the teachers supported the use of autonomy in the ESL classroom. They strongly believed that the learners who are motivated to work autonomously proved to be more confident and successful learners. The idea of practising autonomy in the English language classroom was reported as a tool for effective learning as exploring certain information help students learn some extra information. The research described that autonomy can never be taken as learning the language in isolation. Even at the university level, the role of a teacher is vital in fostering autonomy in the classroom. The teacher should be responsible for the selection of material, and her/his role must be that of a facilitator, instructor, guide, observer, and evaluator. The teachers unanimously believed that without the teacher's presence, it is almost impossible for the learners to select appropriate materials and resources of learning for themselves.

The study, however, directed towards some limitations of the educational system of Pakistan. The study reported that the educational system does not support autonomy and independent learning. The prevailing education system is coursecentred and exam-centred which does not allow teachers to decide upon where the students should be autonomous and active in learning. The research reaches the conclusion that a teacher's role in an ESL classroom should be only to observe and moderate the student's learning, giving them as much autonomy to learn as is possible. Furthermore, most importantly, the teachers in Pakistan need the training to practice learner autonomy in an ESL context as this is relatively a new practice for them.

\section{LIMITATION AND FURTHER RESEARCH DIRECTIONS}

The concept of learner autonomy is new in Pakistan, and only a few studies have been carried on. The present study is conducted by collecting information from the university teachers of five universities in the South Punjab of Pakistan. 19 ESL teachers were selected as the data was supposed to be collected through the interviews. The area of the research may be expanded, and more data may be collected to generalise the results obtained from the present study. More studies can be conducted by collecting data from the students as well. Additionally, research can also be steered by administering some close-ended questionnaire(s), focus group discussions and case studies, etc.

\section{AUTHORS' CONTRIBUTION}

Asma Kashif Shahzad worked on the overall research design of the study. She worked on developing the research tool, collection, and interpretation of data.

Akifa Imtiaz conducted interviews with the teachers and transcribed the recorded interviews. She worked on the literature review and interpretation of the data.

Tahira Asgher contributed to the organisation of the writing process, transcription, and interpretation of the recorded interviews.

\section{REFERENCES}

1. Allwright, D. (1990). Autonomy in language pedagogy in CRILE Working Paper 6. Centre for Research in Education: University of Lancaster.

2. Aoki, N. (2000). Affect and the role of teacher in the development of learner autonomy. In J. Arnold (Ed.), Affect in language learning (pp. 142-154). Beijing: Foreign Language Teaching and Research Press.

3. Aslam, M. Z. \& Yasmeen, M. (2018). Learner Autonomy: Pakistani Learners' Perceptions, Attitudes, Motivation and Challenges. Hayatian Journal of Linguistics and Literature. Pp. 145-170

4. Boonma, N., \& Swatevacharkul, R. (2020). The effect of autonomous learning process on learner autonomy of English public speaking students. Indonesian Journal of Applied Linguistics, 10(1), 194-205. ttps://doi.org/10.17509/ijal.v10i1.25037

5. Borg, S., \& Al-Busaidi, S. (2012). Teachers' beliefs and practices regarding learner autonomy. ELT Journal, 66(3), 283-292. https://doi.org/10.1093/elt/ccr065 
6. Broady, E., \& Kenning, Marie-Madeleine. (Eds.). (1996). Promoting learner autonomy in university language teaching. London: Middlesex University Printing Services.

7. Dickinson, L. (1994). Preparing learners: Toolkit requirements for preparing/orienting learners. In E. Esch (Ed.), Self-access and the adult language learner(39-49). London: CILT.

8. Falah Alzubi, A., Kaur Mehar Singh, M., \& Pandian, A. (2017). The Use of Learner Autonomy in English as a Foreign Language Context among Saudi Undergraduate Enrolled in Preparatory Year Deanship at Najran University. Advances in Language and Literary Studies, 8(2), 152-16. https://doi.org/10.7575/aiac.alls .v. 8 n. 2 p. 152

9. Fedj, S. \&Benaissi, F. (2018). Key Conceptions on Learner Autonomy and Particular Links with the Algerian Educational Context. Arab World English Journal. 9. 445-457. https://doi.org/10.24093/awej/vol9no3.30

10. Godwin-Jones, R. (2019). Riding the digital wilds: Learner autonomy and informal language learning. Language Learning \& Technology, 23(1), 8-25.

11. Han, L. G. (2014). Teacher's role in developing learner autonomy: A literature review. International Journal of English Language Teaching, 2, 21-27. https://doi.org/10.5430/ijelt.v1n2p21

12. Ho, J., \&Crookall, D. (1995). Breaking with Chinese cultural traditions: Learner autonomy in English language teaching. System, 23(2), 235-243. https://doi.org/10.1016/0346-251X(95)00011-8

13. Holec. H. (1981). Autonomy in Foreign Language Learning. Oxford: Pergamon.

14. Honarzad, R. \&Rassaei, E. (2019). The Role of EFL Learners' Autonomy, Motivation and Self-efficacy in Using Technology-based Out-of-Class Language Learning Activities. The JALT CALL Journal. 15. https://doi.org/10.29140/jaltcall.v15n3.170

15. Knowles, M. (1975). Self-directed learning: A guide for learners and teachers. Chicago: Association Press.

16. Lai, C. (2017). Autonomous language learning with technology: Beyond the classroom. London: Bloomsbury Publishing.

17. Little, D. (1991). Learner Autonomy1: Definitions, Issues and Problems. Dublin: Authentik.

18. Littlewood, W. (1999). Defining and developing autonomy in East Asian contexts. Applied Linguistics, 20(1), 71-94. https://doi.org/10.1093/applin/20.1.71

19. Liu, X., Liu, Y. \& Tu, J. (2020). Multimedia Technology and Learner Autonomy: An Experimental Study for Asymmetric Effects. Symmetry, 12, 462. https://doi.org/10.3390/sym12030462

20. Nunan, D. (1993). From learning-centeredness to learner-centeredness. Applied Language Learning, 4, 1-18.

21. Shi, W., \& Han, L. (2019). Promoting learner autonomy through cooperative learning. English Language Teaching, 12(8), 30-36. U https://doi.org/10.5539/elt.v12n8p30

22. Sinclair, B. (2000). Learner autonomy: The next phase? In B. Sinclair, I. McGrath \& T. Lamb (Eds.), Learner autonomy, teacher autonomy: Future directions (pp. 4-14). Harlow: Longman.

23. Smith, R. (2003).Pedagogy for autonomy as (becoming-) appropriate methodology. In D. Palfreyman\& R. C. Smith (Eds.), Learner autonomy across cultures: Language education perspectives (129-146). Basingstoke: Palgrave Macmillan. https://doi.org/10.1057/9780230504684_8

24. Schneider, S., Nebel, S., Beege, M., \& Rey, G.D. (2018). The autonomy-enhancing effects of choice on cognitive load, motivation and learning with digital media. Learning and Instruction, 58, 161-172. https://doi.org/10.1016/j.learninstruc.2018.06.006

25. Voller, P. (1997). Does the teacher have a role in autonomous language learning? In P. Benson, \& P. Voller (Eds.), Autonomy and independence in language learning (pp. 98-113). London: Longman. https://doi.org/10.4324/9781315842172-9

26. Wu, Z. (2018). Positioning (mis)aligned: The (un)making of intercultural asynchronous computer mediated communication. Language Learning \& Technology, 22(2), 75-94.

27. Xu, J. F. (2007). The theory and practice of university foreign language autonomous learning. Beijing: China Social Sciences Publishing House.

28. Xu, J. F., \& Xu. L. (2004). Exploring College English teachers' roles in the autonomous learning mode. Higher Education Research, 3, 77-79.

29. Yang, N. (1998). Exploring a new role for teachers: promoting learner autonomy. System, 26, 127-135. https://doi.org/10.1016/S0346-251X(97)00069-9

30. Yasmin, M., \& Sohail, A. (2018b). A creative alliance between learner autonomy and English language learning: Pakistani university teachers' beliefs. Creativity Studies, 11(1), 1-9. https://doi.org/10.3846/2345 0479.2017.1406874

31. Yasmin, M., \& Sohail, A. (2018c). Realising learner autonomy in Pakistan: EFL teachers' beliefs about their practices. International Journal of English Linguistics; 8(2), 153-162. https://doi.org/10.5539/ijel.v8n2p153

32. Yasmin, M., Sohail, A., Sarkar, M., \& Hafeez, R. (2017). Creative Methods in Transforming Education Using Human Resources. Creativity Studies, 10(2), 145-158. https://doi.org/10.3846/23450479.2017.1365778

33. Yildiz, J. \&Yucedal, H. (2020). Learner Autonomy: A Central Theme in Language Learning. International Journal of Social Sciences and Educational Studies, 7, 208-212. https://doi.org/10.23918/ijsses.v7i3p208

34. Yildiz, Y. (2017). Components of Commitment to the Teaching Profession. International Journal of Social Sciences \& Educational Studies, 4(2), 115-122. https://doi.org/10.23918/ijsses.v4i2sip115 
35. Yildiz, Y., \&Celik, B. (2017). Commitment to the teaching profession. International Journal of Social Sciences \& Educational Studies, 4(2), 93-97. https://doi.org/10.23918/ijsses.v4i2sip115

36. Zhong, Q. (2018). The Evolution of Learner Autonomy in Online Environments: A Case Study in a New Zealand Context. Studies in Self-Access Learning Journal, 9, 71-85. https://doi.org/10.37237/090106 